\title{
Language Evaluation in Developmental Language Disorder: Celf 4 vs Celf 5
}

\author{
Esther Moraleda Sepulveda ${ }^{1}$, Patricia López Resa ${ }^{1} \&$ Noelia Pulido García ${ }^{1}$ \\ ${ }^{1}$ Health Sciences Faculty, Castilla-La Mancha University, Spain \\ Correspondence: Esther Moraleda Sepulveda, Professor, Health Sciences Faculty, Castilla-La Mancha University, \\ Avda Real Fábrica de la Seda s/n. CP 45600 Talavera de la Reina (Toledo), Spain. E-mail: esther.moraleda@ \\ uclm.es, pallapaty@hotmail.com, noeliapulidogarcia@hotmail.com
}

Received: May 3, 2021; Accepted: May 21, 2021; Published: May 24, 2021

\begin{abstract}
The CELF assessment test is one of the tools most used today for the differential diagnosis of Developmental Language Disorder (DLD) because it allows obtaining a lingüistic level with different areas. The recent update of the test offers new scales especially in Spanish speakers. The objective of this study was to analyze the language level of people with DLD with the CELF 4 and CELF 5 tests to verify the possible differences that exist between both tests. The sample consisted of 26 children and adolescents with a diagnosis of TDL between 6 and 15 years old who were evaluated with both tests. The results obtained indicate that, in general, the scores are lower when they are evaluated with the CELF 5 test, with significant differences in Core Language, Receptive Language and Expressive Language. These data lead us to consider the CELF test as an essential tool in the diagnosis of DLD but also to take into account a complementary evaluation that allows obtaining a complete linguistic profile as a starting point for the intervention.
\end{abstract}

Keywords: develomental language disorder, assesment, Celf 4 test, Celf 5 test

\section{Introduction}

Language Developmental Disorder/ Specific Language Impairment (LDL/SLI) is characterized by being one of the most prevalent alterations in learning difficulties, with a prevalence of approximately 7\% (Sans et al, 2012). The main characteristics that define SLD/LDD include the difficulty in acquiring oral language, but without cognitive and sensorial deficits, or neurological alterations, and those that affect the functioning or configuration of organs participating in speech (Adams \& Lloyd, 2005; Bishop \& Norbury, 2002 and Botting; Conti-Ramsden, 2003).

It, therefore, seems clear that language development does not follow the usual pattern that takes place in typical development (TD), and persistent difficulties appear in various language areas (Andreu et al., 2014; Muñoz-Yunta et al., 2005). Children with this alteration face problems to both acquire and develop language (Rodríguez et al., 2017). Children may present deficits in structural language components, but associated pragmatic disorders might also exist because of them (Adams \& Lloyd, 2005; Bishop \& Norbury, 2002; Botting \& Conti-Ramsden, 2003).

In the phonology area of people with LDL/SLI, an incorrect phonological disorder, limitations in the phonological system, limited syllable patterns and variations in incorrect forms tend to appear (Coll-Florit, 2013; Kalábová, 2009).

In the lexical area, children with LDL/SLI present alterations, their word language is often altered (Gray, 2003; Oetting et al., 1995 and Rice et al., 1992), they are slower to name images and make lexical decisions (Edwards \& Lahey, 1996; Lahey \& Edwards, 1999), and they have difficulties learning semantic information about new words (Alt et al., 2004; Alt \& Plante, 2006 and Kail \& Leonard, 1986). They make more naming mistakes than their peers and they offer more incomplete definitions (McGregor et al., 2002).

Studies on morphosyntax indicate that a linguistic knowledge deficit exists. For instance, people with LDL/SLI present deficits when building grammatical sentences (Fukuda et al., 2002). Indeed several studies have indicated that some Spanish-speaking children present marked limitations in adjective-agreement inflections (Bedore \& Leonard, 2001), problems with using clitic articles or pronouns (Anderson, 2001; Anderson \& Lockowitz, 2009; Hincapié-Henao et al., 2008; Restrepo \& Gutiérrez-Clellen, 2004) and difficulties in verbal inflections (Bedore \& Leonard, 2001; Grinstead et al., 2013; Aguilar-Mediavilla et al., 2002). 
In pragmatic terms, the scientific literature reports the frequent use of gestures as a strategy to make up for lexical difficulties, having little conversational initiative, or difficulties in using narrative and conversational strategies, or describing facts, and poorly interacting with adults by being limited to take turns in a question-answer format (Andreu et al., 2007). Difficulties also appear in reciprocal social interactions (Bishop, 1997; Leonard \& Bortolini, 1998).

Therefore, it has apparently been demonstrated that subjects with LDL/SLI present marked heterogeneity in linguistic profiles because both their different language skills (phonetics, phonology, morphosyntax, semantics and pragmatics), and the type of language they employ (receptive and/or production), are selectively committed (Marini et al., 2008; Verhoevenet al., 2011).

Hence the use of valid protocols to measure these variables, and having a high degree of sensitivity and specificity is essential (Mendoza, 2011; Lietos \& Belén, 2017). According to Acosta (2012), not only the way that subjects process language in given contexts, but also the socio-cultural factors that guide learning and language acquisition, must be considered when contemplating an evaluation. Along the same lines, Baker and Chenery (1999) and Carballo (2012) report that preparing an efficient intervention design depends on both the quality of the evaluation and the information obtained with it to a great extent (Howlin \& Kendal, 1991).

Therefore, one of the most first important aspects to bear in mind when facing an LDL/SLI evaluation process is the early identification of the disorder, which centers on completely preventing the disorder or reducing any possible harmful effects (Semel et al., 2006; Stevenson, 2003). Given the prototypical linguistic alterations of LDL/SLI, carrying out a receptive and expressive language evaluation by applying standard tools is fundamental to diagnose it (Fleckstein et al., 2018).

\section{CELF 4 VS. CELF 5}

The most frequently used standard tests include the Clinical Evaluation of Language Fundamentals (CELF) (Semel et al., 2003). CELF is able to very accurately identify subjects with LDL/SLI (Aguado, 2009). Some authors indicate that this is because the specificity and sensitivity of CELF is $89 \%$ and $100 \%$, respectively, and its corresponding cutoff points in relation to standard deviations of -1.5 are crucial questions to correctly identify LDL/SLI (Acosta et al., 2013; Conti-Ramsden et al., 2001; Wilson et al., 1991; Wood et al., 2016).

CELF 4 (2006) is a tool that is individually administered to subjects aged 5-21 years. It allows individuals' strong and weak points to be identified, the seriousness of the disorder to be established, and enables subjects with LDL/SLI to be diagnosed and followed up. It provides recommendations for efficient interventions (Carvallo et al., 2014) which, in turn, permit the clinical decision-making process to be reflected (Paslowki, 2005; Semel et al., 2006). Its detailed description appears in Table 1.

Table 1. The CELF 4 structure. Modified from Carvallo et al. (2014)

\begin{tabular}{|c|c|c|}
\hline Age: $5-8$ years & Age: $9-12$ years & Age: $13-21$ years \\
\hline \multicolumn{3}{|c|}{ LEVEL 1. IDENTIFY IF A LANGUAGE DISORDER EXISTS OR NOT. } \\
\hline Core language score & Core language score & Core language score \\
\hline Concepts and following directions & Concepts and following directions & Recalling sentences \\
\hline Word structure & Recalling sentences & Formulating sentences \\
\hline Recalling sentences & Formulating sentences & Total word classes 2 . \\
\hline Formulating sentences & Word classes 2. & Definitions of words. \\
\hline \multicolumn{3}{|c|}{ LEVEL 2. DESCRIBING THE NATURE OF THE DISORDER } \\
\hline Receptive Language Index & Receptive Language Index & Receptive Language Index \\
\hline Concepts and following directions & Concepts and following directions & Word classes 2 (receptive part) \\
\hline $\begin{array}{l}\text { Word classes } 1 \text { and } 2 \text { (receptive } \\
\text { part). } \\
\text { Sentence structure. }\end{array}$ & Word classes 2 (receptive part). & Understanding paragraphs \\
\hline Expressive Language Index & Expressive Language Index & Expressive Language Index \\
\hline Word structure & Recalling sentences & Recalling sentences \\
\hline Recalling sentences & Formulating sentences & Formulating sentences \\
\hline Formulating sentences & Word classes 2 (expressive part). & $\begin{array}{l}\text { Word classes } 2 \text { (expressive } \\
\text { part). }\end{array}$ \\
\hline Language Content Index & Language Content Index & Language Content Index \\
\hline
\end{tabular}


Concepts and following directions

Total word classes 1 and 2 .

Expressive vocabulary
Total word classes 2

Expressive vocabulary (Age 9)

Definitions of words (Ages 10-21)

Understanding paragraphs.

Working Memory Index

Concepts and following directions

Recalling sentences

Formulating sentences
Definitions of words (ages 10-

21)

Understanding paragraphs.

\section{Working Memory Index}

Recalling sentences

Formulating sentences

Formulating sentences

Sentence structure

Nonetheless, the updated and more recently published CELF (CELF 5; 2018) presents many improvements compared to the previous version, of which the following stand out: a student performance evaluation process in class, or a classification guide based on the observation that analyses communication performance at school and home. Whereas the test elements in the fourth edition evaluate a given language skill, the fifth allows each subtest to be used independently of the rest (Douglass et al., 2019; Hessling \& Schuele, 2020).

As for modifications in the test format, we find an independent evaluation of linguistic concepts and directional concepts, and stimuli that evaluate the most primary semantic relations have been included. Unlike former versions, CELF 5 allows the semantic component to be evaluated from the age of 5 years, and new elements to be included which boost the upper and lower limits of comprehension tests (Oetting et al., 2019; Scheidnes \& Redmond, 2019).

Regarding changes to contents, some subtests have been removed given their poor use, and also because other specific protocols exist to evaluate them, such as referential naming capacity, phonological awareness or familiar sequences. New pragmatic evaluation subtests have also been included to allow social interactions to be analyzed, such as "verifying pragmatic skills" (Forbes, 2019; Poth, 2020).

It is also worth highlighting that CELF 5 is typified and validated for many special groups like LDL/SLI, learning disorders with reading-writing difficulties and Autism Spectrum Disorder (Matsuzaki et al, 2019). The CELF 5 structure is found in Table 2.

Table 2. CELF 5 structure. Modified from Wiig et al. (2018)

\begin{tabular}{|c|c|c|}
\hline Age: $5-8$ years & Age: $9-12$ years & Age: $13-15$ years \\
\hline \multicolumn{3}{|c|}{ EVALUATING LANGUAGE IN CONTEXT. } \\
\hline $\begin{array}{l}\text { Language } \\
\text { questionnaire. }\end{array}$ & $\begin{array}{l}\text { Language } \\
\text { questionnaire. }\end{array}$ & $\begin{array}{l}\text { Language } \\
\text { questionnaire. }\end{array}$ \\
\hline \multicolumn{3}{|c|}{$\begin{array}{l}\text { IDENTIFYING PROBLEMS, DESCRIBING THE NATURE OF THE DISORDER, DETERMINING } \\
\text { THE INTERVENTION }\end{array}$} \\
\hline Core language index (CLI) & Core language index (CLI) & Core language index (CLI) \\
\hline Understanding sentences & Related words & Writing sentences \\
\hline Morphosyntax & Repeating & Repeating sentences \\
\hline Writing sentences & sentences & Understanding oral texts \\
\hline Repeating sentences & Semantic relations & Semantic relations \\
\hline Receptive Language Index (RLI) & Receptive Language Index (RLI) & $\begin{array}{l}\text { Receptive Language } \\
\text { (RLI) }\end{array}$ \\
\hline Understanding sentences Related & Related words & Relate \\
\hline words & Performing indi & Un \\
\hline Performing indications & Semantic relations & Semantic relations \\
\hline Expressive Language Index (ELI) & $\begin{array}{l}\text { Expressive Language Index } \\
\text { (ELI) }\end{array}$ & $\begin{array}{l}\text { Expressive Language Index } \\
\text { (ELI) }\end{array}$ \\
\hline Morphosyntax & Writing sentences & Writing sentences \\
\hline Writing sentences & ig sente & Repeating sente \\
\hline Repeating sentences & Word puzzle & Word \\
\hline Language Content Index (LCI) & Language Content Index (LCI) & Language Content Index (LCI) \\
\hline Language concepts & Related words & words \\
\hline Related words & anding oral texts & Understanding oral texts \\
\hline Performing indications & Defining words & Word puzzle \\
\hline Language structure index (LSI) & Language structure index (LSI) & Language structure index (LSI) \\
\hline
\end{tabular}




$\begin{array}{lll}\text { Understanding sentences } & \text { Performing indications } & \text { Performing indications } \\ \text { Morphosyntax } & \text { Writing sentences } & \text { Writing sentences } \\ \text { Writing sentences } & \text { Repeating sentences } & \text { Repeating sentences } \\ \text { Repeating sentences } & \end{array}$

Evaluating social communication skills.

Profile of pragmatic skills

"verifying pragmatic skills"

Having analyzed both tests, this study aimed to compare the different language indices between them to verify if a correlation exists between the different areas in people with LDL/SLI.

\section{Method}

\subsection{Participants}

In the present research work, 26 people diagnosed with DLD/SLI (22 males, 4 females) participated. They were divided into two age groups according to the distinction that the different evaluation tests make, $6-8$ years $(8$ children) and 9-15 years (18 youths), according to the different age groups established for the test. The first group had a mean chronological age of 7.37 years (0.74), and the second group had one of 11.83 years (2.4).

\subsection{Procedure}

We first we contacted several LDL/SLI associations and private clinics to know people diagnosed with LDL/SLI and their interest in participating in this study. After centers had accepted and confirmed the sample subjects, an informed consent document was sent to parents to confirm their participation in the study. Informed consent had been approved by our University's Ethics Committee. After signing this document in both cases, a language evaluation was carried out during four sessions: two for CELF 4 and two for CELF 5. Tests were randomly performed with at least 1 month between one time point and the next. Both tests were printed and handed out.

\subsection{Instrument}

In order to make the language evaluation, the complete standard CELF 4 (Spanish Clinical Evaluation of Language Fundamentals-4) test version was used (Wiig, Secord \& Semel, 2003). This test was administered to populations aged between 5 and 22 years to evaluate the language level in several areas: core language, receptive language, expressive language, language content, language structure and working memory.

The CELF 5 test (Wiig, Secord \& Semel, 2018) addresses youths aged from 5 to 15 years. This test offers five types of compound scores for language level: the core language index (CLI), the receptive language index (RLI), the expressive language index (ELI) the language content index (LCI), the working memory index (WMI).

Both these tests distinguish age groups: one is for 5-8 year-olds and the other for youths aged 9 years and more.

In the present study, a decision was made to use the first four areas of both tests because they are comparable in both. This was not the case with language structure and working memory (that appear in CELF 4) and the language memory index (CELF 5). We were unable to compare the pragmatic area because it is not included in CELF 4.

\subsection{Data Analysis}

Sample normality was verified by the Kolmogorov-Smirnoff test, which was parametric. The Bonferroni post hoc test was then applied. Next the results were analyzed by the Student's t-test of independent samples. Pearson's correlation coefficient was employed to analyze any correlation between both instruments.

\section{Results}

The results obtained in the different evaluation test areas are found in Table 3. The data obtained with the participants in both groups were generally lower for performance in CELF 5 than in CELF 4. Medium scores can be observed in table 3 .

Table 3. Mean direct scores in the different CELF 4 and CELF 5 areas

\begin{tabular}{llll}
\hline Areas & Age & CELF 4 & CELF 5 \\
\hline CLI & 6-8 years & 90.88 (11.07) & $81.38(11.08)$ \\
& 9-15 years & $81.11(16.80)$ & $70.06(16.82)$ \\
\hline RLI & 6-8 years & 93.25 (16.40) & $84.25(12.58)$ \\
& 9-15 years & $81.83(19.22)$ & $75.61(17.62)$ \\
\hline
\end{tabular}


Standard deviation in brackets

\begin{tabular}{llll}
\hline ELI & 6-8 years & $90.63(11.16)$ & $76.88(12.61)$ \\
& 9-15 years & $82.33(14.45)$ & $69.61(17.46)$ \\
\hline LCI & 6-8 years & $91.38(9.0)$ & $85.13(12.12)$ \\
& 9-15 years & $80.33(17.43)$ & $78.89(22.45)$ \\
\hline
\end{tabular}

When correlating the scores obtained with both instruments, and by bearing all the participants in mind, we found differences when comparing various areas. For the CLI, significant differences appeared between both lots of data $(\mathrm{t}(25)=4.32, \mathrm{p}<.01)$. Differences were also significant for the RLI $(\mathrm{t}(25)=2.13, \mathrm{p}<.05)$ and the ELI $(\mathrm{t}(25)=4.95$, $\mathrm{p}<.01)$. Nonetheless, no significant differences were observed for the $\operatorname{LCI}(\mathrm{t}(25)=.85, \mathrm{p}>.05)$.

\section{Discussion}

Our data demonstrate that both CELF 4 and CELF 5 are evaluation instruments that can be used as a starting point to diagnose LDL/SLI, as evidenced by different research works of recent years (Peña et al., 2020; Ramírez-Santana et al., 2019; Wright et al., 2018). Nevertheless, some characteristics ought to be taken into account. Some items in the original version have been modified, which has altered the tests that comprise each index. This led to lower results being obtained for CELF 5 than those obtained for CELF 4. There was no correlation between the different CELF 4 and 5 tests, except for the LCI. This is a striking finding because content subtests have been removed from the more recent version (CELF 5), which were in the previous version.

One of the reasons for this could lie in the test evaluation which, for CELF 4, was performed in Spanish-speaking children and children from the USA. However, a Spanish-speaking population was employed in the updated version. Therefore, we should also bear in mind a test limitation: evidence for poor test stability in some cases, (Coret \& McCrimmon, 2015). Another explanation would be that despite CELF 4 generally having more items per test, the total number of tests to achieve the overall indices is bigger in CELF 5, which could result in the evaluated individuals feeling tired and not paying enough attention.

Nevertheless, very little research has been conducted into the overall CELF 5 analysis, despite the first studies that focused on investigating the usefulness of specific areas; e.g. understanding sentences (Lituma-Solis, 2019) or the pragmatic area having already appeared (Reid, 2018). Different studies have also taken CELF 5 as a general indicator of language level in other types of disorders like Fragile X Syndrome (Hoffmann et al., 2020), Cerebellar Ataxia Syndrome (Bonne et al., 2016) or difficulties with learning bilingual language (Shenoy, 2015).

Therefore, not limiting the administered CELF test to only diagnose DLD/SLI and supplementing the evaluation with other tools to gain a more global vision of the different language areas are advisable, particularly for developing the lexico-semantic and morphosyntax areas.

\section{References}

Acosta, V. (2012). Algunos retos y propuestas en la conceptualización, evaluación e intervención del Trastorno Específico del Lenguaje (TEL). Revista chilena de fonoaudiología, 11(23). https://doi.org/10.5354/07194692.2012.24525

Acosta, V., Ramírez, G. M., \& Hernández, S. (2013). Identificación y clasificación de alumnado con Trastorno Específico del Lenguaje. Revista de Logopedia, Foniatría y Audiología, 33(4), 157-164. https://doi.org/10.1016/j.rlfa.2013.07.006

Adams, C., \& Lloyd, J. (2005). Elicited and spontaneous communicative functions and stability of conversational measures with children who have pragmatic language impairments. International Journal of Language and Communication Disorders, 40(3), 333-347. https://doi.org/10.1080/13682820400027768

Aguado, G. (2015). Trastornos específicos del lenguaje e hipoacusia. Revista de Logopedia, Foniatría y Audiología, 35(4), 171-176. https://doi.org/10.1016/j.rlfa.2015.07.002

Aguilar-Mediavilla, E. M., Sanz-Torrent, M., \& Serra-Raventos, M. S. (2002). A comparative study of the phonology of pre-school children with specific language impairment (SLI), language delay (LD) and normal $\begin{array}{lllll}\text { acquisition. In Clinical Linguistics and Phonetics, 16(8), 573-596. } & \text {. }\end{array}$ https://doi.org/10.1080/02699200210148394

Alt, M., \& Plante, E. (2006). Factors that influence lexical and semantic fast mapping of young children with specific language impairment. Journal of Speech, Language, and Hearing Research, 49(5), 941-954. https://doi.org/10.1044/1092-4388(2006/068) 
Alt, M., Meyers, C., \& Ancharski, A. (2012). Using principles of learning to inform language therapy design for children with specific language impairment. In International Journal of Language and Communication Disorders, 47(5), 487-498. https://doi.org/10.1111/j.1460-6984.2012.00169.x

Alt, M., Plante, E., \& Creusere, M. (2004). Semantic features in fast-mapping. Journal of Speech, Language, and Hearing Research, 47(2), 407-420. https://doi.org/10.1044/1092-4388(2004/033)

Anderson, R. T. (2001). Lexical morphology and verb use in child first language loss: A preliminary case study investigation. International Journal of Bilingualism, 5(4), 377-401. https://doi.org/10.1177/13670069010050040101

Anderson, R. T., \& Lockowitz, A. (2009). How do children ascribe gender to nouns? A study of Spanish-speaking children with and without specific language impairment. Clinical Linguistics and Phonetics, 23(7), 489-506. https://doi.org/10.1080/02699200902844818

Andreu i Barrachina, L. A., Aguado, G., i Pera, M. C. C., \& Sanz-Torrent, M. (2014). El trastorno especifico del lenguaje: diagnóstico e intervención (Vol. 294). Editorial UOC.

Baker, R., \& Chenery, H. J. (1999). Assessment in speech-language pathology. https://doi.org/10.1177/026553229901600301

Bedore, L. M., \& Leonard, L. B. (2001). Grammatical Morphology Deficits in Spanish-Speaking Children with Specific Language Impairment. Journal of Speech, Language, and Hearing Research, 44(1-4), 905-924. https://doi.org/10.1044/1092-4388(2001/072)

Bishop, D. V. M. (1997). Cognitive neuropsychology and developmental disorders: Uncomfortable bedfellows. Quarterly Journal of Experimental Psychology Section A: Human Experimental Psychology, 50(4), 899-923. https://doi.org/10.1080/713755740

Bishop, Dorothy, V. M., \& Norbury, C. F. (2002). Exploring the borderlands of autistic disorder and specific language impairment: A study using standardised diagnostic instruments. Journal of Child Psychology and Psychiatry and Allied Disciplines, 43(7), 917-929. https://doi.org/10.1111/1469-7610.00114

Bonne, N. L., Evald, L., \& Hansen, J. K. (2016). A case of the cerebellar cognitive affective syndrome in a 12year-old boy with acute post-infectious cerebellar ataxia. European Journal of Paediatric Neurology, 20(3), 480-482. https://doi.org/10.1016/j.ejpn.2016.01.001

Botting, N., \& Conti-Ramsden, G. (2003). Autism, primary pragmatic difficulties, and specific language impairment: can we distinguish them using psycholinguistic markers? Developmental Medicine \& Child Neurology, 45(8), 515-524. https://doi.org/10.1017/S0012162203000963

Carballo, G. (2012). Guía para la evaluación del TEL: algunas consideraciones. Revista de logopedia, foniatría y audiología, 32(2), 87-93. https://doi.org/10.1016/j.rlfa.2012.03.004

Carvallo Hernández, X., Castillo Contreras, P., León D'cunha, C., Morales Verdugo, D., \& Sbarbaro Anders, V. (2014). Aplicación del CELF 4 a niños con trastorno específico del lenguaje y niños con desarrollo típico de 5.0 a 6 años 11 meses de edad.

Cohen, N. J. (2001). Language impairment and psychopathology in infants, children, and adolescents. Sage Publications, reading skills, and communicative competence. Health Psychology Report, 3(1).

Coll-Florit, M. (2013). Trastornos del habla y de la voz. Trastornos del habla y de la voz, 1-177.

Conti-Ramsden, G., Botting, N., \& Faragher, B. (2001). Psycholinguistic markers for specific language impairment (SLI). Journal of child psychology and psychiatry, 42(6), 741-748. https://doi.org/10.1111/14697610.00770

Coret, M. C., \& McCrimmon, A. W. (2015). Test Review: Wiig, E. H., Semel, E., \& Secord, W. A. (2013). Clinical Evaluation of Language Fundamentals-Fifth Edition (CELF-5). https://doi.org/10.1177/0734282914557616

Douglass, J. E., Constantino, C., Alvarado, J., Verrastro, K., \& Smith, K. (2019). Qualitative investigation of the speech-language therapy experiences of individuals who covertly stutter. Journal of fluency disorders, 61, 105713. https://doi.org/10.1016/j.jfludis.2019.105713

Edwards, J., \& Lahey, M. (1996). Auditory lexical decisions of children with specific language impairment. Journal of Speech, Language, and Hearing Research, 39(6), 1263-1273. https://doi.org/10.1044/jshr.3906.1263

Fleckstein, A., Prévost, P., Tuller, L., Sizaret, E., \& Zebib, R. (2018). How to identify SLI in bilingual children: a 
study on sentence repetition in French. Language Acquisition, 25(1), 85-101. https://doi.org/10.1080/10489223.2016.1192635

Forbes, K. (2019). The role of individual differences in the development and transfer of writing strategies between foreign and first language classrooms. Research Papers in Education, 34(4), 445-464. https://doi.org/10.1080/02671522.2018.1452963

Fukuda, S., Fukuda, S., \& Kabani, N. (2002). Specific language impairment: Neurological and linguistic manifestations. McGill Working Papers in Linguistics, 1, 81-118.

Gray, S. (2003). Diagnostic accuracy and test-retest reliability of nonword repetition and digit span tasks administered to preschool children with specific language impairment. Journal of Communication Disorders, 36(2), 129-151. https://doi.org/10.1016/S0021-9924(03)00003-0

Grinstead, J., Baron, A., Vega-Mendoza, M., De la Mora, J., Cantú-Sánchez, M., \& Florese, B. (2013). Tense marking and spontaneous speech measures in Spanish specific language impairment: A discriminant function analysis. Journal of Speech, Language, and Hearing Research, 56(1), 352-363. https://doi.org/10.1044/10924388(2012/11-0289)

Hannus, S. (2018). Children with specific language impairment in primary health care-tests, assessment, prevalence and home activities.

Hessling, A., \& Schuele, C. M. (2020). Individualized Narrative Intervention for School-Age Children With Specific Language Impairment. Language, speech, and hearing services in schools, 51(3), 687-705. https://doi.org/10.1044/2019_LSHSS-19-00082

Hincapié, L., Mario, H., Prieto, G., Lopera, F., David, R., Pineda, A., Rodrigo, S., Rebolledo, C., Pablo, J., Vásquez, L., Stella, N., Villamizar, M., María, Á., Pérez, J., \& Camilo, D. (2008). Trastorno Específico del Desarrollo del Specific Language Impairment in a Colombian Children Sample. Universitas Stuttgart, 7(2), 557-569. http://www.scielo.org.co/scielo.php?script=sci_arttext\&pid=S1657-92672008000200019

Hoffmann, A., Wang, A., Berger, N., Cordeiro, L., Shaffer, R., Tartaglia, N., ... \& Berry-Kravis, E. (2020). Language across the Lifespan in Fragile X Syndrome: Characteristics and Considerations for Assessment. Brain Sciences, 10(4), 212. https://doi.org/10.3390/brainsci10040212

Howlin, P., \& Kendal, L. (1991). Assessing children with language test-which test to use? International Journal of Language and Communication Disorders, 26, 355-367. https://doi.org/10.3109/13682829109012020

Kail, R., \& Leonard, L. B. (1986). Word-finding abilities in language-impaired children. ASHA monographs, (25), 1-39.

Kalábová, M., \& Stehlík, M. P. (2009). Masarykova univerzita Filozofická fakulta Ústav románských jazyků a literatur Los trastornos del lenguaje y la comunicación lingüistica Magisterská diplomová práce.

Lahey, M., \& Edwards, J. (1996). Why do children with specific language impairment name pictures more slowly than their peers? Journal of Speech, Language, and Hearing Research, 39(5), 1081-1098. https://doi.org/10.1044/jshr.3905.1081

Leonard, L. B., \& Bortolini, U. (1998). Grammatical morphology and the role of weak syllables in the speech of Italian-speaking children with specific language impairment. Journal of Speech, Language, and Hearing Research, 41(6), 1363-1374. https://doi.org/10.1044/jslhr.4106.1363

Lietos, M., \& Belén, A. (2017). Evaluación en el Trastorno Específico del Lenguaje (TEL).

Lituma-Solis, D. (2019). Examining Diagnostic Utility of CELF-5 Sentence Comprehension Test.

Marini, A., Tavano, A., \& Fabbro, F. (2008). Assessment of linguistic abilities in Italian children with specific $\begin{array}{llll}\text { language } \quad \text { impairment. } & \text { 28uropsychologia, }\end{array}$ https://doi.org/10.1016/j.neuropsychologia.2008.05.013

Matsuzaki, J., Kuschner, E. S., Blaskey, L., Bloy, L., Kim, M., Ku, M., ... \& Roberts, T. P. (2019). Abnormal auditory mismatch fields are associated with communication impairment in both verbal and minimally verbal/nonverbal children who have autism spectrum disorder. Autism Research, 12(8), 1225-1235. https://doi.org/10.1002/aur.2136

McCathren, R., Warren, S., \& Yoder, P. (1996). Prelinguistic predictors of later language development. In K. N. Cole, P. S. Dale, \& D. J. Thal (Eds.), Assessment of Communication and language. Baltimore: Paul Brookers

McGregor, K. K., Newman, R. M., Reilly, R. M., \& Capone, N. C. (2002). Semantic representation and naming in 
children with specific language impairment. Journal of Speech, Language, and Hearing Research, 45(5), 998-1014. https://doi.org/10.1044/1092-4388(2002/081)

Mendoza, E. (2011). Perfiles psicolingüísticos diferenciales en niños con trastorno específico del lenguaje (TEL). Actas del III Congreso Internacional del Colegio de Logopedas de Cataluña, 4-8.

Muñoz Yunta, J. A., Palau Baduell, M., Salvadó Salvadó, B., Rosendo Moreno, N., Valls Santasusana, A., Perich Alsina, X., García Morales, I., Fernández, A., Maestú Unturbe, F., \& Ortiz Alonso, T. (2005). Trastornos específicos del lenguaje: diagnóstico, tipificación y estudios con magnetoencefalografía. Revista de Neurología, 40(S01), S115. https://doi.org/10.33588/rn.40s01.2005080

Oetting, J. B., Berry, J. R., Gregory, K. D., Rivière, A. M., \& McDonald, J. (2019). Specific language impairment in African American English and southern white English: Measures of tense and agreement with dialectinformed probes and strategic scoring. Journal of Speech, Language, and Hearing Research, 62(9), 34433461. https://doi.org/10.1044/2019_JSLHR-L-19-0089

Oetting, J. B., Rice, M. L., \& Swank, L. K. (1995). Quick incidental learning (QUIL) of words by school-age children with and without SLI. Journal of Speech and Hearing Research, 38(2), 434-445. https://doi.org/10.1044/jshr.3802.434

Paslowki, T. (2005). The Clinical Evaluation of Language Fundamentals, Fourth Edition (CELF4): A Review. Canadian Journal of School Psychology, 20(129). https://doi.org/10.1177/0829573506295465

Peña, E. D., Bedore, L. M., Lugo-Neris, M. J., \& Albudoor, N. (2020). Identifying Developmental Language Disorder in School Age Bilinguals: Semantics, Grammar, and Narratives. Language Assessment Quarterly, 1-18. https://doi.org/10.1080/15434303.2020.1827258

Poth, L. D. (2020). Language and Communication Abilities in Adolescents with Fetal Alcohol Spectrum Disorders (Doctoral dissertation, UC San Diego).

Ramírez-Santana, G. M., Acosta-Rodríguez, V. M., \& Hernández-Expósito, S. (2019). A comparative study of language phenotypes in autism spectrum disorder and specific language impairment. Psicothema, 31(4), 437442 .

Reid, R. (2018). Comparing two naturalistic pragmatic assessments: The celf-5 pragmatic activities and the Yale in vivo pragmatic protocol (yipp).

Restrepo, M. A., \& Gutiérrez-Clellen, V. F. (2004). Grammatical impairments in Spanish-English bilingual children. Bilingual language development and disorders in Spanish-English speakers, 213-234.

Rice, M. L., Wexler, K., \& Hershberger, S. (1998). Tense over time: The longitudinal course of tense acquisition in children with specific language impairment. Journal of Speech, Language, and Hearing Research, 41(6), 1412-1431. https://doi.org/10.1044/jslhr.4106.1412

Richterová, E., \& Málková, G. S. (2017). Specific language impairment in the long-term perspective-the importance of assessment procedures, reading skills, and communicative competence. Health Psychology Report, 3(1). https://doi.org/10.5114/hpr.2017.69660

Rodríguez, M. T., Gómez, I. M., Prieto-Ayuso, A., \& Gil-Madrona, P. (2017). La educación psicomotriz en su contribución al desarrollo del lenguaje en niños que presentan necesidades específicas de apoyo educativo. Revista de investigación en logopedia, 7(1), 89-106.

Sans, A., Boix, C., Colomé, R., López-Sala, A., \& Sanguinetti, A. (n.d.). Trastornos del aprendizaje.

Scheidnes, M., \& Redmond, L. (2019). Object Relative Clause Comprehension in L2 Children with Limited L2 Exposure.

Semel, E., Messing, E., Secord, W. A., \& Wayne A. (2018) CELF 5: evaluación clínica de los fundamentos del lenguaje. Madrid: Pearson Clinical \& Talent Assessment

Semel, E., Wiig, E. H., \& Secord, W. A. (2006). CELF 4. Clinical Evaluation of Language Fundamentals. Spanish Edition. United States of America: PsychCorp

Shenoy, S. (2015). Assessing English language learners in L1 Kannada and L2 English to identify students who are at risk for language learning disabilities (Doctoral dissertation, UC Berkeley).

Spiker, D., Boyce, G. C., \& Boyce, L. K. (2002). Parent-child interactions when young children have disabilities. In International Review of Research in Mental Retardation, 25, 35-70). Academic Press. https://doi.org/10.1016/S0074-7750(02)80005-2 
Stevenson, J. (2003). Specific learning disorders: primary and secondary prevention. Developmental Medicine and Child Neurology, 45(42). https://doi.org/10.1111/j.1469-8749.2003.tb04658.x

Verhoeven, L., Steenge, J., \& van Balkom, H. (2011). Verb morphology as clinical marker of specific language impairment: Evidence from first and second language learners. Research in Developmental Disabilities, 32(3), 1186-1193. https://doi.org/10.1016/j.ridd.2011.01.001

Wiig, E. H., Secord, W., \& Semel, E. (2006). Clinical evaluation of language fundamentals—Preschool. Second UK edition.

Wilson, K. S., Blackmon, R. C., Hall, R. E., \& Elcholtz, G. E. (1991). Methods of language assessment: A survey of California public school clinicians. Language, Speech, and Hearing Services in Schools, 22(4), 236-241. https://doi.org/10.1044/0161-1461.2204.236

Wood, C., Diehm, E. A., \& Callender, M. F. (2016). An investigation of language environment analysis measures for Spanish-English bilingual preschoolers from migrant low-socioeconomic-status backgrounds. Language, Speech, and Hearing Services in Schools, 47(2), 123-134. https://doi.org/10.1044/2015_LSHSS-14-0115

Wright, L., Pring, T., \& Ebbels, S. (2018). Effectiveness of vocabulary intervention for older children with (developmental) language disorder. International journal of language \& communication disorders, 53(3), 480-494. https://doi.org/10.1111/1460-6984.12361

\section{Copyrights}

Copyright for this article is retained by the author(s), with first publication rights granted to the journal.

This is an open-access article distributed under the terms and conditions of the Creative Commons Attribution license (http://creativecommons.org/licenses/by/4.0/). 